\title{
Hubungan Faktor Risiko Karies Gigi dengan Status Karies Gigi pada Anak Usia Dini (Studi pada TK Pelita Takwa, Pondok Betung, Tangerang Selatan)
}

\author{
Yufitri Mayasari
}

Departemen Ilmu Kesehatan Gigi Masyarakat dan Pencegahan, Fakultas Kedokteran Gigi Universitas Prof. Dr. Moestopo (Beragama), Jakarta, Indonesia

Email: yufitrimayasari@ dsn.moestopo.ac.id

Disubmisi: 16 Juli 2021; direvisi: 29 Juli 2021; diterima: 31 Juli 2021

\begin{abstract}
Basic health research of Indonesia in 2018 showed that early childhood caries affected 93\% of children. Early dental caries risk assessment using a dental caries risk simulator could be used to determine the appropriate program to prevent dental caries. This study was aimed to analyze the relationship between risk factors and dental caries status in early childhood. This was an analytical study with a cross sectional design using total sampling method. There were 51 preschool children at Taman Kanak Kanak (kindergaten school) Pelita Takwa, Pondok Betung, South Tangerang as samples. Dental caries was assessed by using the def-t index and dental caries risks were assessed by using the Irene's donut program. Interactive interviews with parents were conducted to determine the risk factors for dental caries among the students. The results showed that the prevalence of dental caries was $84.3 \%$ and the mean def-t was 5.35. The chi-square test was carried out to determine the relationship between dental caries status and risk factors. The result was not significant for three questions related to the factors, as follows: the child's tooth surface had white spots, the acidity level of the child's teeth was below pH 6.5, and the mother's age was 36 years old. Albeit, twelve other risk factors were shown to be associated with dental caries status. In conclusion, the prevalence of dental caries in preschool children was still high. Risk factors related to the dental caries status among pre-school children can be used as educational materials targeting pre-school children and their parents.
\end{abstract}

Keywords: caries risk; dental caries; preschool children

\begin{abstract}
Abstrak: Riset Kesehatan Dasar Indonesia tahun 2018 menunjukkan bahwa 93\% anak usia dini mengalami karies gigi. Penilaian risiko karies gigi sejak dini menggunakan simulator risiko karies gigi dapat menjadi salah satu cara untuk menentukan program yang tepat dalam mencegah terjadinya karies gigi. Penelitian ini bertujuan untuk menganalisis hubungan faktor risiko dengan status karies gigi pada anak usia dini. Jenis penelitian ialah analitik dengan desain potong lintang menggunakan metode total sampling. Sampel yang diperoleh sebanyak 51 anak usia dini di sekolah Taman Kanak-Kanak Pelita Takwa, Pondok Betung, Tangerang Selatan. Karies gigi dinilai menggunakan indeks def-t dan risiko karies subjek dinilai menggunakan program Irene's donut. Wawancara interaktif dengan orang tua dilakukan untuk mengetahui faktor risiko terjadinya karies gigi pada pasien tersebut. Hasil penelitian mendapatkan prevalensi karies gigi sebesar $84,3 \%$ dengan rerata def-t 5,35. Uji chi-square terhadap hubungan status karies gigi dengan faktor risiko mendapatkan hasil tidak bermakna pada tiga pertanyaan terkait faktor permukaan gigi anak ada bercak putih, tingkat keasaman kuman gigi anak di bawah $\mathrm{pH} 6,5$, dan usia ibu 36 tahun ke atas. Dua belas faktor risiko lainnya terbukti memiliki hubungan dengan status karies gigi. Simpulan penelitian ini ialah prevalensi karies gigi pada anak prasekolah masih tinggi. Faktor-faktor risiko yang terbukti memiliki hubungan dengan status karies gigi anak dapat dijadikan materi edukasi dengan sasaran anak pra sekolah serta orang tuanya.
\end{abstract}

Kata kunci: risiko karies; karies gigi; anak usia pra sekolah 


\section{PENDAHULUAN}

Karies gigi masih menjadi masalah utama kesehatan gigi masyarakat. Prevalensi karies gigi masih masih pada tingkat yang tinggi terutama di negara berkembang. ${ }^{1}$ Hasil dari Riset Kesehatan Dasar (Riskesdas) 2018 mendapatkan sebanyak $57,6 \%$ orang Indonesia memiliki masalah gigi dan mulut dan $93 \%$ anak Indonesia menderita karies gigi. ${ }^{2}$ Angka prevalensi dan insidensi karies gigi yang cukup tinggi menunjukkan kurangnya motivasi dan kesadaran masyarakat baik untuk mencegah terjadinya karies gigi sejak dini.

Karies gigi merupakan penyakit yang disebabkan multifaktorial dengan faktor etiologi utamanya ialah bakteri plak Streptococcus mutans. ${ }^{1}$ Penilaian faktor risiko sangat penting dilakukan untuk mengidentifikasi risiko karies gigi pada anak secara dini sehingga dapat dilakukan tindakan pencegahan karies gigi. Konsep penilaian faktor risiko tersebut harus dilakukan dengan identifikasi individual pada tiap anak. ${ }^{3}$ Berdasarkan latar belakang ini maka penulis terdorong untuk menganalisis lebih lanjut mengenai hubungan status karies gigi dengan faktor-faktor risiko pada siswa Taman Kanak-Kanak agar dapat dilakukan tindakan pencegahan karies gigi sedini mungkin.

\section{METODE PENELITIAN}

Penelitian ini merupakan penelitian analitik dengan desain potong lintang. Pengambilan data dilakukan secara total sampling pada 51 anak usia pra sekolah di TK Pelita Takwa, Pondok Betung, Tangerang Selatan. Status karies gigi dilakukan dengan pemeriksaan gigi mulut menggunakan indeks deft dan risiko karies gigi menggunakan simulator risiko karies Donut Irene. Penilaian ini dilakukan dengan wawancara interaktif kepada orang tua siswa mengenai faktor-faktor yang memiliki risiko terjadinya karies gigi.

Indeks DMF merupakan indeks aritmatika untuk karies yang kumulatif dalam suatu populasi. ${ }^{4}$ Pada indeks ini semua gigi diperiksa kecuali molar tiga karena biasanya tidak tumbuh, sudah dicabut, atau tidak berfungsi. Indeks ini tidak menggunakan skor pada kolom yang tersedia langsung diisi kode gigi yang berlubang karena karies gigi $(\mathrm{D}=$ Decay), gigi yang hilang karena pencabutan akibat karies gigi ( $\mathrm{M}=$ Missing ), dan gigi yang ditumpat karena karies gigi $(\mathrm{F}=$ Filled $)$. Indeks serupa untuk gigi sulung ialah def-t dan def-s di mana e menunjukkan gigi yang diekstraksi (untuk membedakan terjadi kehilangan gigi karena pergantian gigi alami ) dan $\mathrm{f}$ menunjukkan gigi yang di tumpat atau bagian permukaan gigi. ${ }^{4}$

Rumus def-t rata-rata

def- $\mathrm{t}==\frac{\text { Jumlah } \mathrm{d}+\mathrm{e}+\mathrm{f}}{\text { Jumlah orang yang diperiksa }}$

Kriteria dalam perhitungan rata-rata DMF$\mathrm{T}$ atau def-t menurut WHO ialah sebagai berikut: $^{4}$
a. Nilai rerata $0,0-1,1=$ kategori sangat
rendah
b. Nilai rerata $1,2-2,6=$ kategori rendah
c. Nilai rerata $2,7-4,4=$ kategori sedang
d. Nilai rerata 4,5-6,5 = kategori tinggi
e. Nilai rerata $>6,6 \quad=$ kategori sangat tinggi

Simulator Risiko Karies (SRK) “Irene's donut" adalah program interaktif sebagai alat komunikasi antara petugas kesehatan (dokter gigi dan perawat gigi) dengan orang tua murid agar pendidikan kesehatan gigi kepada orang tua murid lebih menarik dan efektif. Program ini dikembangkan dari software komputer sebagai hasil disertasi dari DR. drg. Irene Adyatmaka. Faktor risiko penyebab gigi berlubang yang dikomunikasikan dalam SRK merupakan hasil penelitian terhadap 2800 anak usia TK dengan melibatkan sekitar 50 faktor dan ternyata yang benar-benar bermakna ialah 15 faktor yang dikelompokan sebagai berikut:

1. Faktor kebiasaan/gaya hidup anak yang berisiko; dapat diperbaiki (1 s.d. 5)

2. Faktor kondisi gigi anak; dapat diperbaiki (6 s.d. 8)

3. Faktor "predisposisi"; tidak dapat diperbaiki, namun dapat dicegah dengan upaya perhatian khusus (9 s.d. 13)

4. Faktor pengetahuan, sikap dan perilaku orang tua; dapat diperbaiki (14 s.d. 15) 
Tujuan SKR untuk memudahkan orang tua siswa mensimulasikan risiko kerusakan gigi anak dan mengetahui cara mengatasinya.

\section{HASIL PENELITIAN}

Terdapat 51 pasangan ibu-anak yang ikut serta dalam penelitian ini. Pemeriksaan gigi dan mulut dilakukan dengan menggunakan indeks deft dan wawancara interaktif dengan ibunya menggunakan 16 pertanyaan mengenai risiko karies gigi dengan pilihan jawaban "YA" dan "TIDAK". Hasil penelitian mendapatkan bahwa siswa yang berjenis kelamin laki-laki lebih banyak daripada perempuan $(57 \%$ : 43\%). Dari 51 siswa yang diperiksa, terdapat $84,3 \%$ dengan status karies gigi dan 5,7\% non-karies gigi. Rerata siswa memiliki 5,35 $\pm-3,532$ karies gigi.

Gambar 1 memperlihatkan hasil penilaian risiko karies gigi menggunakan Irene's donut simulator. Daftar pernyataan yang dijawab "TIDAK" oleh mayoritas responden penelitian (ibu dari pasangan ibu-anak) yaitu minum softdrink dalam 1 minggu, minum susu lebih 4 kali dalam sehari, minum susu menggunakan botol hingga 4 tahun lebih, kebiasaan ngemut permen tiap hari, ngemut makanan, usia ibu 36 tahun ke atas, setujukah: gigi berlubang tidak mengganggu tumbuh kembang anak, dan setiap hari membiarkan anak menyikat gigi sen- diri. Adapun daftar pertanyaan yang dijawab "YA" oleh mayoritas responden yaitu gigi belakang anak ada garis kehitaman, permukaan gigi anak ada bercak putih, tingkat keasaman kuman gigi anak di bawah pH 6,5, tingkat pendidikan ibu SLTA ke bawah, pemberian ASI ke anak hingga usia anak 1 tahun ke atas, anak sekarang berusia 4 tahun ke atas, anak diasuh keluarga sendiri, dan gigi anak ada yang berlubang.

Tabel 2 memperlihatkan uji hubungan risiko karies gigi dan status karies gigi. Dari daftar pertanyaan risiko karies gigi yaitu pertanyaan: minum softdrink dalam 1 minggu, minum susu lebih 4 kali dalam sehari, minum susu menggunakan botol hingga 4 tahun lebih, kebiasaan ngemut permen tiap hari, ngemut makanan, gigi belakang anak ada garis kehitaman, tingkat pendidikan ibu setingkat akademi/SLTA ke bawah, anak diberikan ASI hingga 1 tahun ke atas, anak sekarang berusia 4 tahun ke atas, anak diasuh keluarga sendiri, setujukah: gigi berlubang tidak mengganggu tumbuh kembang anak, dan setiap hari membiarkan anak menyikat gigi sendiri memperoleh nilai $\mathrm{p} \leq 0,05$ pada hasil uji chi-square. Untuk daftar pertanyaan berikut ini, yaitu: permukaan gigi anak ada bercak putih, tingkat keasaman kuman gigi anak di bawah pH 6,5, dan usia ibu 36 tahun ke atas memperoleh nilai $\mathrm{p}>0,05$ pada hasil uji chi-square.

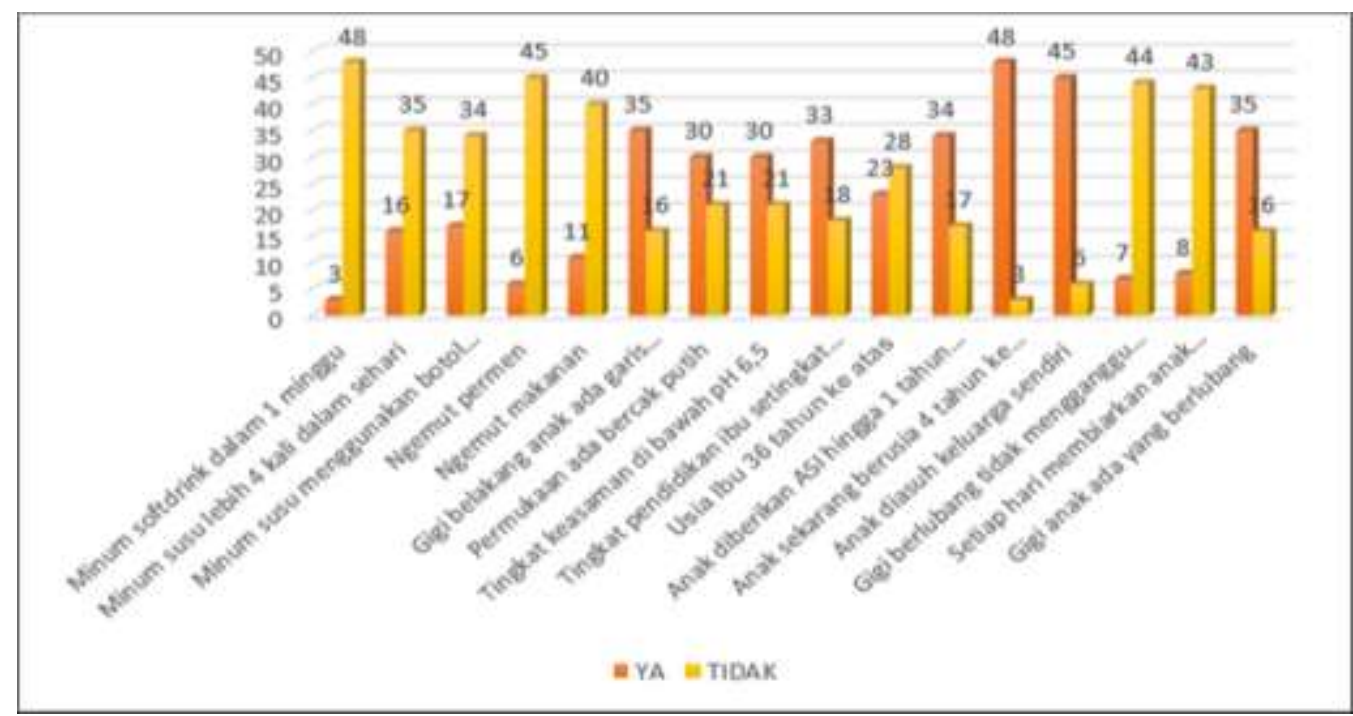

Gambar 1. Hasil penilaian risiko karies gigi menggunakan Irene's donut simulator 
Tabel 2. Hubungan risiko karies gigi dan status karies gigi

\begin{tabular}{|c|c|c|c|}
\hline & $\begin{array}{c}\text { Karies } \\
\text { gigi }\end{array}$ & $\begin{array}{l}\text { Non-karies } \\
\text { gigi }\end{array}$ & Nilai $p$ \\
\hline \multicolumn{4}{|c|}{ 1.Anak minum softdrink dalam 1 minggu lebih dari 1 kali } \\
\hline Ya & 2 & 1 & $0,000^{*}$ \\
\hline Tidak & 41 & 7 & \\
\hline \multicolumn{4}{|c|}{ 2.Anak minum susu lebih 4 kali dalam sehari } \\
\hline $\mathrm{Ya}$ & 13 & 3 & $0,008 *$ \\
\hline Tidak & 30 & 5 & \\
\hline \multicolumn{4}{|c|}{$\begin{array}{l}\text { 3.Anak minum susu menggunakan botol hingga } 4 \text { tahun } \\
\text { lebih }\end{array}$} \\
\hline Ya & 15 & 2 & $0,017 *$ \\
\hline Tidak & 28 & 6 & \\
\hline \multicolumn{4}{|c|}{ 4.Anak suka ngemut permen tiap hari } \\
\hline $\mathrm{Ya}$ & 4 & 2 & $0,000 *$ \\
\hline Tidak & 39 & 6 & \\
\hline \multicolumn{4}{|c|}{ 5.Anak suka ngemut makanan } \\
\hline Ya & 11 & 0 & $0,000 *$ \\
\hline Tidak & 32 & 8 & \\
\hline \multicolumn{4}{|c|}{ 6.Gigi belakang anak ada garis kehitaman } \\
\hline Ya & 34 & 1 & $0,008 *$ \\
\hline Tidak & 9 & 7 & \\
\hline \multicolumn{4}{|c|}{ 7.Permukaan gigi anak ada bercak putih } \\
\hline $\mathrm{Ya}$ & 28 & 2 & 0,208 \\
\hline Tidak & 15 & 6 & \\
\hline \multicolumn{4}{|c|}{ 8. Tingkat keasaman kuman gigi anak di bawah pH 6,5} \\
\hline Ya & 26 & 4 & 0,208 \\
\hline Tidak & 17 & 4 & \\
\hline \multicolumn{4}{|c|}{ 9.Tingkat pendidikan ibu setingkat akademi/SLTA ke bawah } \\
\hline $\mathrm{Ya}$ & 26 & 7 & $0,036^{*}$ \\
\hline Tidak & 17 & 1 & \\
\hline \multicolumn{4}{|c|}{ 10.Usia ibu 36 tahun ke atas } \\
\hline Ya & 20 & 3 & 0,484 \\
\hline Tidak & 23 & 5 & \\
\hline \multicolumn{4}{|c|}{ 11.Saat masih bayi, anak diberikan ASI hingga 1 tahun ke atas } \\
\hline Ya & 30 & 4 & $0,017 *$ \\
\hline Tidak & 13 & 4 & \\
\hline \multicolumn{4}{|c|}{ 12.Anak sekarang berusia 4 tahun ke atas } \\
\hline Ya & 42 & 6 & $0,000^{*}$ \\
\hline Tidak & 1 & 2 & \\
\hline \multicolumn{4}{|c|}{ 13Anak diasuh keluarga sendiri (bukan baby -sitter) } \\
\hline Ya & 37 & 8 & $0,000 *$ \\
\hline Tidak & 6 & 0 & \\
\hline \multicolumn{4}{|c|}{$\begin{array}{l}\text { 14.Setujukah: gigi berlubang tidak mengganggu tumbuh } \\
\text { kembang anak }\end{array}$} \\
\hline $\mathrm{Ya}$ & 6 & 1 & $0,000^{*}$ \\
\hline Tidak & 37 & 7 & \\
\hline \multicolumn{4}{|c|}{$\begin{array}{l}\text { 15.Setiap hari membiarkan anak menggosok gigi sendiri tanpa } \\
\text { diawasi }\end{array}$} \\
\hline Ya & 7 & 1 & $0,000 *$ \\
\hline Tidak & 36 & 7 & \\
\hline
\end{tabular}

*Uji chi square, $\mathrm{p} \leq 0,05$ 


\section{BAHASAN}

Pada penelitian yang dilakukan terhadap 51 anak usia pra sekolah di Pondok Betung, Tangerang Selatan diperoleh 57\% sampel berjenis kelamin laki-laki dan $84,3 \%$ sampel memiliki karies gigi. Berdasarkan Riset Kesehatan Dasar (Riskesdas) 2018, sebanyak $57,6 \%$ orang Indonesia memiliki masalah gigi dan mulut dan $93 \%$ anak Indonesia menderita karies gigi. ${ }^{2}$ Hal ini sejalan dengan penelitian di Australia, yang melaporkan bahwa 50\% dari anak usia 6 tahun mengalami karies gigi pada gigi susu. ${ }^{5}$ Hasil penelitian di Qatar juga menunjukkan $89,2 \%$ anak menderita karies gigi. ${ }^{6}$ Usia anak masih menjadi masalah karena memiliki prevalensi terbesar karies gigi. Terjadinya karies gigi pada anak usia dini dapat memengaruhi kondisi gigi dan mulutnya pada usia selanjutnya. Milsom et $\mathrm{al}^{7}$ menyatakan bahwa anak yang memiliki karies gigi memiliki 5-6 kali risiko lebih tinggi membentuk lesi baru dibandingkan anak yang bebas karies.

Rerata sampel penelitian memiliki $5,35 \pm 3,532$ karies gigi, artinya dalam setiap mulut anak terdapat rerata 5 hingga 6 gigi bermasalah akibat karies gigi. Gambar 1 memperlihatkan hasil penilaian risiko karies gigi menggunakan Irene's donut simulator yang mendapatkan daftar pernyataan yang dijawab "TIDAK" oleh mayoritas responden yaitu minum softdrink dalam satu minggu, minum susu lebih 4 kali dalam sehari, minum susu menggunakan botol hingga usia 4 tahun lebih, kebiasaan ngemut permen tiap hari, ngemut makanan, usia ibu 36 tahun ke atas, setujukah: gigi berlubang tidak mengganggu tumbuh kembang anak, dan setiap hari membiarkan anak menyikat gigi sendiri. Adapun daftar pertanyaan yang dijawab "YA" oleh mayoritas responden penelitian yaitu gigi belakang anak ada garis kehitaman, permukaan gigi anak ada bercak putih, tingkat keasaman kuman gigi anak di bawah $\mathrm{pH}$ 6,5, tingkat pendidikan ibu SLTA ke bawah, pemberian ASI ke anak hingga usia anak 1 tahun ke atas, anak sekarang berusia 4 tahun ke atas, anak diasuh keluarga sendiri, dan gigi anak ada yang berlubang.

Tabel 2 memperlihatkan uji hubungan risiko karies gigi dan status karies gigi. Berdasarkan uji tersebut diketahui dari daftar pertanyaan risiko karies gigi didapatkan bahwa pada pertanyaan: minum softdrink dalam satu minggu, minum susu lebih 4 kali dalam sehari, minum susu menggunakan botol hingga 4 tahun lebih, kebiasaan ngemut permen tiap hari, ngemut makanan, gigi belakang anak ada garis kehitaman, tingkat pendidikan ibu setingkat akademi/SLTA ke bawah, anak diberikan ASI hingga 1 tahun ke atas, anak sekarang berusia 4 tahun ke atas, anak diasuh keluarga sendiri, setujukah: gigi berlubang tidak mengganggu tumbuh kembang anak, dan setiap hari membiarkan anak menyikat gigi sendiri. Hasil uji chi-square mendapatkan nilai $\mathrm{p} \leq 0,05$. Kebiasaan minum softdrink dalam 1 minggu merupakan salah satu faktor kebiasaan anak yang terbukti memiliki hubungan dalam menyebabkan terjadinya karies gigi. Beberapa penelitian yang dilakukan di Australia menyatakan terdapat hubungan kuat antara kebiasaan minum softdrink dengan skor Indeks DMFT. ${ }^{8}$ Sifat minuman softdrink dengan $\mathrm{pH}$ yang rendah menyebabkan larutnya permukaan email sehingga lama kelamaan dapat menyebabkan karies gigi.

Faktor kebiasaan anak yang menjadi risiko terjadinya gigi berlubang yang terbukti memiliki hubungan bermakna dengan terjadinya karies gigi yaitu minum susu lebih dari 4 kali dalam sehari dan minum susu menggunakan botol hingga 4 tahun lebih. Anak usia di bawah 5 tahun sebagian besar memiliki kebiasaan mengonsumsi susu menggunakan botol hingga tertidur. Frekuensi minum susu yang sering (lebih dari 4 kali dalam sehari) dapat menyebabkan asupan gula ke dalam rongga mulut semakin banyak. Bila kebiasaan ini dilakukan terus menerus tanpa memperhatikan kebersihan rongga mulut maka terjadi penumpukan plak yang bersifat kariogenik. Bakteri rongga mulut akan memroduksi asam sehingga menyebabkan terjadinya demineralisasi lapisan email. ${ }^{9,10}$ Konsumsi jus manis juga dapat meningkatkan risiko terjadinya karies gigi. $^{3}$

Faktor kebiasaan anak yang memiliki 
hubungan terjadinya karies gigi yaitu kebiasaan ngemut permen tiap hari. Pola kebiasaan konsumsi permen yang mengandung gula meningkatkan risiko terjadinya karies gigi. Hal ini sejalan dengan hasil penelitian yang dilakukan Yabao et al $^{11}$ dan Abaas ${ }^{12}$ yang mendapatkan rerata DMFT dan deft pada anak yang memiliki kebiasaan makan permen lebih tinggi dibandingkan anak yang mengonumsi softdrink dan es krim. Faktor kebiasaan anak yang terbukti memiliki hubungan terhadap terjadinya karies gigi yaitu kebiasaan ngemut makanan. Kebiasaan ini menyebabkan makanan yang dikonsumsi berada dalam jangka waktu yang lebih lama dalam rongga mulut. Apabila makanan yang dikonsumsi tersebut mengandung karbohidrat dan gula maka bakteri plak akan menghasilkan asam yang menyebabkan terjadinya proses demineralisasi. Pada anak, hal ini dapat menyebabkan masalah yang serius mengingat ketahanan gigi anak lebih rentan terhadap asam. ${ }^{3,13}$

Faktor tingkat pendidikan ibu merupakan faktor predisposisi yang terbukti memiliki hubungan kuat terhadap terjadinya karies gigi yaitu tingkat pendidikan ibu setingkat akademi/SLTA ke bawah. Menurut Cianetti et al, ${ }^{14}$ pendapatan keluarga yang rendah dan tingkat pendidikan yang rendah dari orangtua terkait dengan keberadaan karies gigi pada anak. Selain itu, faktor anak diberikan ASI hingga 1 tahun ke atas juga terbukti memiliki hubungan dalam menyebabkan terjadinya karies gigi pada anak. Peres et al ${ }^{15}$ melaporkan bahwa anak yang disusui lebih dari 24 bulan memiliki risiko 2,4 kali terkena karies gigi dibandingkan anak yang disusui kurang dari 12 bulan (RR 2.4; CI 95\%). Faktor predisposisi lain pada penelitian ini yang terbukti memiliki hubungan kuat terhadap terjadinya karies gigi ialah pertanyaan anak sekarang berusia 4 tahun ke atas. Prevalensi karies gigi merupakan fungsi umur karena karies bersifat progresif akumulatif. $^{4}$

Selain hal-hal yang telah dipaparkan terdapat juga faktor risiko yang tidak dapat diperbaiki namun dapat dicegah dengan upaya perhatian khusus yang memiliki hubungan terhadap terjadinya karies gigi yaitu faktor anak diasuh keluarga sendiri. Berdasarkan penelitian Hosani dan Gunn ${ }^{16}$ yang dilakukan terhadap 421 murid Taman Kanak-kanak di Abu Dhabi didapatkan bahwa peran pengasuh bertanggung jawab pada penyediaan makanan anak. Penyediaan makanan anak berhubungan dengan asupan nutrisi apakah memiliki risiko menyebabkan karies gigi atau tidak. ${ }^{4,16}$

\section{SIMPULAN}

Prevalensi karies gigi pada anak prasekolah masih tinggi. Semua faktor dalam program donat Irene memiliki sarana yang berguna untuk menentukan risiko anak terhadap karies gigi. Penelitian ini mengungkapkan bahwa faktor risiko karies gigi menunjukkan perbedaan pada anak prasekolah dengan dan tanpa karies gigi.

Upaya promosi kesehatan mulut harus dilaksanakan secara efektif dalam meningkatkan kesehatan mulut anak-anak, serta sangat penting adanya pemahaman yang baik tentang pengetahuan dan sikap orang tua serta pengasuh. Hasil penelitian ini dapat membantu memandu dan memodifikasi kegiatan pencegahan kesehatan mulut pada saat ini dan di masa depan.

\section{Konflik Kepentingan}

Penulis menyatakan tidak terdapat konflik kepentingan pada studi ini

\section{Ucapan Terima kasih}

Penulis mengucapkan terima kasih kepada kepala sekolah, guru, orang tua, dan siswa TK Pelita Takwa, Pondok Betung, Tangerang Selatan atas bantuannya selama penelitian berlangsung. Penulis juga mengucapkan terima kasih kepada Nadia Nur Aliya Siregar, SKG serta Gyovana Maharani Radianto, SKG yang telah membantu dalam proses pengambilan data pada penelitian ini.

\section{DAFTAR PUSTAKA}

1. Andegiorgish AK, Weldemariam BW, Kifle MM, Mebrahtu FG, Zewde HK, Tewelde MG, et al. Prevalence of dental caries and associated factors among 12 years old students in Eritrea. BMC Oral 
Health. 2017;17(1):169.

2. Riset Kesehatan Dasar. Kementerian Kesehatan Badan Penelitian dan Pengembangan Kesehatan. 2018. Available from: https://www.litbang.kemkes.go.id/lapor an-riset-kesehatan-dasar-riskesdas/

3. Adyatmaka I. Modul simulator risiko karies gigi pada anak prasekolah [Disertasi]. Jakarta: Universitas Indonesia; 2008.

4. Supriatna A, Fadillah RPN, Nawawi AP. Description of dental caries on mixed dentition stage of elementary school students in Cibeber Community Health Center. Padjadjaran J Dent. 2017;29(3): 153-7.

5. Chrisopoulos S, Harford JE. Oral Health and Dental Care in Australia: Key Facts and Figures 2015. Canberra, ACT: Australian Institute of Health and Welfare and the University of Adelaide; 2016.

6. Alkhtib A, Ghanim A, Temple-Smith M, Messer LB, Pirotta M, Morgan M. Prevalence of early childhood caries and enamel defects in four and five-year old Qatari preschool children. BMC Oral Health. 2016;16(1):73.

7. Milsom KM, Blinkhorn AS, Tickle M. The incidence of dental caries in the primary molar teeth of young children receiving National Health Service funded dental care in practices in the North West of England. Br Dent J. 2008;205(7):384-5

8. Armfield JM, Spencer AJ, Roberts-Thomson $\mathrm{KF}$, Plastow K. Water fluoridation and the association of sugar-sweetened beverage consumption and dental caries in Australian children. Am J Public Health. 2013;103:494-500.

9. Colak H, Dulgergil CT, Dalli M, Hamidi MM. Early childhood caries update: a review of causes, diagnoses, and treatments. J
Nat SCi Biol Med. 2013;4(1):29-38.

10. Avila WM, Pordeus IA, Paiva SM, Martins CC. Breast and bottle feeding as risk factors for dental caries: a systematic review and meta-analysis. PLoS One. 2015;10(11). Article ID e0142922.

11. Yabao RN, Duante CA, Velandria FV, Lucas A. Prevalence of dental caries and sugar consumption among 6-12 years old schoolchildren in Benguet, Philippines. Eur J Clin Nutr. 2005;59:1429-38.

12. Abaas HF. Prevalence of dental caries and the effect of sugar's types, frequency of sugar intake and tooth brushing practice on dental caries among children aged 79 years in Wassit governorate-Iraq. $\mathbf{J}$ Bagh Coll Dent 2011;23(special issue):151-4.

13. Pourhashemi SJ, Motlagh MG, Khaniki GRJ, Golestan B. Nutritional assessment of micronutrients in primary school children and its association with anthropometric indices and oral health. Pakistan Journal of Nutrition. 2007;6(6):687-92.

14. Cianetti S, Lombardo G, Lupatelli G, Rossi G, Abraha I, Pagano S, et al. Dental caries, parents educational level, family income and dental service attendance among children in Italy. Eur J Paediatr Dent. 2017;18(1);15-8.

15. Peres KG, Nascimento GG, Peres MA, Mittinty MN, Demarco FF, Santos IS, et al. Impact of prolonged breastfeeding on dental caries: a population-based birth cohort study. Pediatrics. 2017;140(1) e20162943.

16. Hosani ALE, Gunn AJR. The relationship between diet and dental caries in 2 and 4 year old children in the Emirate of Abu\& Dhabi. Saudi Dental Journal. 2000;12(3):149-55. 